\title{
TRADISI ZIARAH DI JAWA TENGAH
}

\author{
Endah Sri Hartatik \\ Jurusan Sejarah Fakultas IImu Budaya Universitas Diponegoro
}

\begin{abstract}
This article discusses the ceremony khol in the community in some areas in Central Java, which the Islamic Mataram period covered in the territory of Negara Agung, Mancanegara, and Pasisiran. Khol tradition in this region is associated with the sacred figures deemed instrumental in the spread of Islam and became an important tool in the preservation of the values associated with harmony and mutual cooperation as the cornerstone to developing social solidarity.
\end{abstract}

Key words: ceremony, tradition, khol, harmony, social solidarity, Central Java.

\section{Pendahuluan}

Setiap masyarakat baik yang berada di daerah yang terpencil maupun perkotaan memiliki warisan kebudayaan yang bervariasi dan memiliki ciri berbeda antara wilayah yang satu dengan lainnya. Warisan budaya itu ada yang masih terlihat jelas sampai sekarang dan ada pula yang tinggal berupa artefak. Sebagian dari warisan budaya itu masih lestari dan terawat dengan baik sampai sekarang.

Upacara tradisi sebagai media penyampaian pesan budaya yang telah digunakan jauh sebelum manusia mengenal tulisan masih terus berlanjut sampai sekarang. Sebagian besar masyarakat melestarikan upacara tradisi untuk berbagai kepentingan. Bagi masyarakat pendukungnya, pelestarian upacara tradisi untuk sebagian juga didasarkan pada alasan bahwa upacara tradisi itu sudah menjadi suatu yang lumrah karena sejak lahir mereka telah mengikuti kebiasaan itu. Upacara Garebeg Maulud di Keraton Surakarta dan Yogyakarta, misalnya, terus dilaksanakan oleh keluarga dari kedua istana itu karena upacara tradisi itu sudah menjadi kebiasaan yang mereka warisi dari nenek moyangnya sejak zaman Sultan Agung. Masyarakat di Kabupaten Demak menyelenggarakan tradisi Garebeg Besar pada setiap bulan Besar menurut kalender Jawa karena tradisi itu telah mereka warisi secara turun-temurun. Mereka tidak berani meninggalkannya karena takut terkena dampak buruk jika tidak melaksanakannya.

Upacara-upacara tradisi yang masih berkembang dalam masyarakat Jawa Tengah cukup banyak dan bervariasi, antara lain berhubungan dengan alam, daur hidup manusia, dan tokoh yang dikeramatkan. Tulisan ini membahas tentang upacara tradisi di makam-makam tokoh suci di Jawa Tengah, khususnya di Grobogan, Sukoharjo, Kebumen, Temanggung, Tegal, dan Kudus.

\section{Upacara Tradisi di Negara Agung, Mancanegara, dan Pasisiran}

Upacara tradisi dalam masyarakat Jawa Tengah dapat dibedakan menurut berbagai cara. Berdasarkan lingkungan alam, upacara tradisi dapat dibedakan menjadi upacara tradisi dalam masyarakat di lingkungan pesisir, pedalaman, dan pegunungan. Berdasarkan lingkungan budayanya dapat dibedakan antara upacara tradisi di Kota Kerajaan (Kuthagara), Negara Agung, Mancanegara, dan Pasisiran. Upacara tradisi di lingkungan budaya yang berdekatan dengan keraton dihubungkan dengan tokoh keraton, sedangkan di wilayah yang jauh dengan keraton, yaitu di Pasisiran, berhubungan dengan tokoh agama.

Upacara tradisi dalam masyarakat Jawa Tengah yang berhubungan dengan makam tokoh suci berdasarkan lingkungan 
budaya tersebar di lingkup Kuthagara sampai Pasisiran. Berdasarkan penelitian, ada kecenderungan bahwa upacara itu berhubungan dengan ulang tahun kematian (khol) tokoh yang dimakamkan dan upacara penggantian kelambu makam itu. Sebagian besar pengunjung upacara tradisi itu mencari tuah dari tokoh yang dimakamkan. Tuah disimbolkan dalam bentuk potongan kelambu makam, makanan sesaji, dan air untuk menyucikan pusaka (jamasan). Tulisan ini mengambil sampel upacara tradisi di Kabupaten Grobogan dan Sukoharjo yang mewakili wilayah Negara Agung, di Kabupaten Kebumen dan Temanggung yang mewakili wilayah Mancanegara, dan di Kabupaten Tegal dan Kudus yang mewakili wilayah Pasisiran.

Upacara tradisi di makam tokoh keramat di Kabupaten Grobogan dilaksanakan di makam Ki Ageng Selo yang berlangsung pada setiap bulan Syakban, sedangkan di Kabupaten Sukoharjo berlangsung di sekitar makam Ki Ageng Banyubiru (Ki Ageng Purwoto Sidiq). Upacara tradisi di Kabupaten Kebumen dilaksanakan di makam tokoh kharismatik Syeh Ibrahim Asmorokondi pada setiap bulan Sura, sedangkan di Kabupaten Temanggung berlangsung di makam Kyai Ageng Mangkukuhan di Puncak Gunung Sumbing pada setiap malem selikuran atau tanggal 20-21 Ramadan. Upacara tradisi di Kabupaten Kudus berupa upacara buka luwur (penggantian kelambu) di makam Sunan Kudus pada setiap tanggal 10 Muharram, sedangkan di Kota Tegal berlangsung di makam Mbah Panggung pada setiap tanggal 6 Syakban.

\section{Pihak yang Terlibat dan Proses Upacara}

Sebagian dari upacara tradisi sudah mengalami perubahan karena beberapa faktor, antara lain (1) jiwa zaman yang sudah berubah, sehingga pelaksanaan upacara tradisi pun telah disesuaikan dengan kebutuhan masyarakatnya, (2) pendukung upacara tradisi sudah mengalami penurunan baik dalam hal jumlah maupun tokoh yang terlibat, dan (3) sumber dana sebagai penyokong utama pelaksanaan upacara tradisi.
Dalam setiap pelaksanaan upacara tradisi baik yang dilakukan secara besarbesaran maupun sederhana membutuhkan keterlibatan beberapa pihak di setiap wilayah antara lain: 1) Juru kunci, yang bertanggung jawab pada waktu diadakan sukuran dengan bancaan sego takir (nasi dalam tempat daun yang di buat sebagai alas) dilengkapi dengan lauk pauk. Juru kunci juga berfungsi sebagai mediator bagi para pengunjung yang datang untuk berziarah; 2) takmir masjid tempat upacara tradisi khol dilaksanakan; 3) panitia khol, yang terdiri dari panitia pengajian bil qoib, panitia pengajian bil simak, dan panitia pengajian umum; 4) jamaah tahlil, yang terdiri dari warga masyarakat sebagai pendukung dana utama; 5) pejabat muspika dan kepala desa setempat yang diminta untuk memberi sambutan pembukaan; 6) masyarakat partisipan dari luar desa dan daerah yang hadir untuk mencari berkah dan masyarakat yang sudah berhasil mencapai keinginannya berkat ziarah; 7) mubaligh/ustad yang memimpin pengajian akbar pada malam puncak upacara tradisi khol tokoh yang dikeramatkan; 8) masyarakat di sekitar makam dan desa di mana tokoh tersebut dimakamkan sebagai sponsor dan partisipan utama upacara tradisi khol; 9) para penabuh rebana yang datang dari dalam dan luar daerah; 10) para pedagang yang memanfaatkan peluang untuk mencari rezeki dengan menjajakan barang dagangannya; 11) tukang parkir dadakan yang menyediakan jasa untuk menjaga kendaraan para pengunjung yang datang dari berbagai daerah.

\subsection{Upacara Khol Ki Ageng Selo di Grobogan dan Kyai Ageng Purwoto Sidiq di Sukoharjo}

Upacara khol di Desa Selo Kecamatan Tawangharjo Kabupaten Grobogan berkaitan erat dengan tokoh kharismatik Ki Ageng Selo yang dipercaya mampu menangkap petir. Masyarakat Grobogan sampai sekarang masih mengucapkan "cleret putrane Ki Ageng Selo" apabila mereka mendengar petir saat hujan deras. Dengan mengucap kalimat itu mereka percaya akan dilindungi dari ancaman sambaran petir. Upacara khol dilaksanakan untuk memperingati ulang 
tahun kematian $\mathrm{Ki}$ Ageng Selo yang dilaksanakan pada setiap tanggal 15 malam 16 bulan Ruwah/Syakban. Ulang tahun kematian ini diperingati dengan membaca Alqur'an dan tahlil secara bergantian di dalam masjid untuk mendoakan Ki Ageng Selo. Pada masa sekarang, pada puncak upacara khol diadakan pengajian akbar dengan mengundang mubaligh. Untuk melaksanakan upacara ini dibentuk kepanitiaan yang disusun secara tetap yang terdiri atas takmir masjid di kompleks makam Ki Ageng Selo.

Upacara tradisi ini dilaksanakan dalam beberapa tahap yaitu tahap persiapan dan pelaksanaan. Tahap pelaksanaan terbagi dalam dua bagian yaitu pembacaan tahlil dan Alqur'an dan pengajian akbar. Pada tahap persiapan dilakukan kerja bakti membersihkan makam dan di seputar makam Ki Ageng Selo yang dipimpin oleh juru kunci makam. Kerja bakti juga dilakukan di masjid yang dipimpin oleh ketua pelaksana yang biasanya dipegang oleh ketua takmir masjid itu beserta panitia dan masyarakat. Di halaman depan masjid di pasang tratag yang digunakan untuk duduk para tamu undangan dan sekaligus membuat podium untuk pidato dan ceramah ustad. Tempat duduk tamu undangan ditata berjajar sesuai dengan jabatannya, sedangkan masyarakat kebanyakan ada yang duduk di kursi dan ada yang duduk di dalam masjid sambil mendengarkan ceramah pada waktu diadakan pengajian akbar.

Sejak dua tiga hari menjelang $\mathrm{khol} \mathrm{Ki}$ Ageng Selo, banyak orang dari luar kota yang datang untuk berziarah ke makamnya. Mereka datang sambil menunggu puncak perayaan khol pada tanggal 15-16 Syakban. Ziarah dipimpin oleh juru kunci makam dan dilanjutkan dengan melakukan tahlil di makam Ki Ageng Selo dan lek-lekan (tak tidur semalam) bagi mereka yang ingin melakukannya. Pada saat inilah terjadi sinkretisme antara budaya Islam dan Hindu yaitu semedi dan membaca tahlil. Berdasarkan informasi dari juru kunci, mereka yang melaksanakan ritual ini biasanya mempunyai keinginan tertentu.
Mereka percaya bahwa dengan berdoa di makam orang-orang suci, keinginan mereka akan dikabulkan oleh Allah SWT. Sebagai kompensasi dari doa yang dikabulkan, mereka akan datang dan memberi sumbangan pada waktu acara khol ini dilaksanakan.

Pembacaan kitab suci Alqur'an dilaksanakan dengan dua cara yaitu hapalan (bil qoib) dan membaca (bin nazar). Bacaan tahlil dilantunkan setelah membaca Alqur'an selesai. Pembacaan Alqur'an bin nazar dimulai setelah sholat Isya pada tanggal 13 Syakban. Pembacaan dilakukan secara bergiliran dari juz pertama sampai juz terakhir oleh 30-40 orang. Pada tanggal 14 Syakban dilaksanakan pembacaan Alqur'an dengan cara hapalan. Tidak semua orang bisa melakukannya, sehingga pembacaan dilakukan hanya oleh beberapa orang saja. Kadang-kadang panitia harus mendatangkan orang-orang yang hapal Alqur'an dari luar desa yaitu Desa Bandungsari atau Desa Mayahan di Kecamatan Wirosari. Bagi mereka yang tidak hapal Alqur'an mengikuti acara itu dengan mendengarkan sambil membaca doa tahlil. Pembacaan Alqur'an secara hapalan dimulai setelah sholat Isya' sampai sekitar pukul 1 dinihari. Orang-orang yang membaca Alqur'an mendapatkan makanan dari warga masyarakat setempat, yang dikumpulkan dalam tempelang yang dibungkus daun pisang beserta lauk pauknya.

Pengajian akbar dilaksanakan setelah sholat Isya, dimulai pada sekitar pukul 8 malam. Susunan acara dalam puncak upacara khol Ki Ageng Selo adalah sebagai berikut.

a) Pembukaan, ditandai dengan pembacaan ayat suci Alqur'an dan terjemahannya oleh petugas yang ditunjuk.

b) Laporan ketua panitia.

c) Sambutan-sambutan yang dilakukan secara bergantian mulai dari Bupati Grobogan atau yang mewakili, Camat Tawangharjo atau yang mewakili, dan Kepala Desa Selo. 
d) Pembacaan riwayat singkat Ki Ageng Selo oleh Juru Kunci Makam.

e) Selingan, diisi dengan penampilan kelompok seni rebana yang didatangkan dari desa lain. Jumlah anggota kelompok seni ini mencapai 20 orang yang terdiri atas penabuh dan penyanyi.

f) Pembacaan tahlil secara massal yang dipimpin oleh ustad yang diundang.

g) Pengajian/ceramah yang disampaikan oleh ustad yang diundang. Tema yang diminta disesuaikan dengan kebutuhan, tetapi umumnya mengenai peningkatan keimanan, kerukunan antarumat beragama, dan wejangan untuk generasi muda supaya mau bekerja keras dan menghargai orang yang lebih tua (Hartatik, dkk., 2009: 103-110).

Sementara itu upacara tradisi $\mathrm{khol}$ di makam Ki Ageng Banyubiru atau dikenal juga dengan Kebo Kanigoro, salah seorang putra Majapahit, berlangsung di Dukuh Sarehan Jatingarang Kecamatan Weru Kabupaten Sukoharjo. Upacara tradisi ini mencapai puncaknya pada bulan Ruwah dalam penanggalan Jawa dan dilaksanakan pada malam hari setelah tanggal dua puluh, misalnya selikur, telulikur, selawe, dan seterusnya, yang merupakan malam hitungan ganjil. Upacara ini diawali dengan penggantian kelambu (pulung langse), bancaan dan selamatan, dan diakhiri dengan pertunjukan wayang kulit semalam suntuk dengan lakon yang telah ditentukan oleh panitia. Dalam tiga tahun terakhir, upacara khol ini dilaksanakan pada bulan Syuro dengan acara wayangan yang tidak direncanakan, dengan lakon Semar Mbangun Kapribaden. Wayangan biasanya didanai oleh orang-orang yang merasa permohonannya yang disampaikan di makam Ki Ageng Purwoto Sidiq telah dikabulkan Tuhan. Permohonan mereka bermacam-macam, misalnya ingin mendapat kenaikan pangkat atau derajat, dagangannya laris, dan segera mendapatkan jodoh.

Selama tiga bulan dalam pelaksanaan upacara khol ini, masyarakat biasanya menyembelih sapi sebagai menu dalam kondhangan. Masakan daging sapi dibagikan kepada seluruh warga setempat. Pada tahun 2007, dari hasil kondhangan terkumpul dana yang cukup besar sehingga dapat tersedia 5 ekor sapi.

Pelaksanaan upacara mulai pada pukul 10 pagi, dengan juru kunci membuka kelambu dan menggantinya dengan kelambu yang baru. Kelambu yang ada selama ini adalah pemberian orang-orang yang permohonannya telah dikabulkan berkat tirakatan di makam Ki Ageng Purwoto Sidiq. Kelambu-kelambu yang telah usang tidak diperebutkan seperti yang terjadi dalam upacara buka luwur di makam Sunan Kudus dan Sunan Muria. Kelambu yang masih baik tetap disimpan oleh juru kunci untuk digunakan kembali. Juru kunci juga menyiapkan sedekahan berupa antara lain jangan menir, pecel pitik (srundeng dan suwiran ayam), pisang, nasi uduk, nasi golong, dan ayam ingkung. Makanan yang disediakan juru kunci merupakan kareman Ki Ageng Banyubiru, yang oleh modin dan juru kunci didoakan sesuai dengan ujub atau tujuannya, dan kemudian dimakan bersama-sama dengan menggunakan pincuk dari daun pisang.

Upacara tradisi ini telah mengalami perubahan ke arah yang lebih sederhana. Di samping itu, Islamisasi terutama dari Muhammadiyah telah membuat sebagian warga masyarakat mulai meninggalkan upacara tradisi ini. Oleh karena itu, orangorang yang datang untuk mengikuti upacara tradisi itu justru kebanyakan berasal dari warga masyarakat luar (wawancara dengan Widodo pada 20 Mei 2008).

Masyarakat paling banyak terlibat dalam upacara tradisi ini pada waktu pelaksanaan selamatan dan pentas wayang kulit semalam suntuk. Lakon yang dipergelarkan dalam setiap tahun berbedabeda, tergantung dari permintaan paniti pelaksana. Untuk mendorong generasi muda agar mereka mau membangun daerahnya, misalnya, lakon yang diminta adalah Semar Mbangun Kayangan. Bagi mereka yang tidak mau terlibat dalam upacara itu tidak mendapat sanksi apapun, 
karena keikutsertaan dalam upacara ini bersifat sukarela (Iswari, dkk., 2008: 64-83).

\subsection{Upacara Khol Syeh Ibrahim Asmorokondi di Desa Kuwarisan Kebumen dan Malam Selikuran di Puncak Gunung Sumbing Temanggung}

Upacara tradisi khol Syeh Ibrahim Asmorokondi di Desa Kuwarisan Kecamatan Panjer Kabupaten Kebumen diselenggarakan pada malam Jum'at Kliwon setiap bulan Sura. Upacara ini diselenggarakan secara rutin setiap tahun, dan pada tahun 2007 bahkan masuk dalam catatan Museum Rekor Indonesia (MURI) karena berhasil membawa ingkung ayam jantan kampung sebanyak 6000-an di pelataran masjid Banyumudal. Banyaknya ingkung ayam tersebut karena setiap kepala keluarga membawa ingkung lebih dari satu. Warga masyarakat setempat yang berada di luar desa atau merantau ke kota juga biasa menitipkan ingkung ayam kepada saudara mereka yang tinggal di desa itu untuk dibawa ke masjid.

Tujuan penyelenggaraan upacara tradisi ini adalah untuk berdoa bersama untuk keselamatan bagi semua warga baik yang ada di desa maupun yang berada di luar desa Kuwarisan. Ada pula warga masyarakat yang menyebut upacara ini sebagai ungkapan syukur kepada Allah SWT atas keselamatan dan kesejahteraan yang mereka dapatkan (wawancara dengan Juharman pada 23 Mei 2005).

Puncak upacara tradisi ini diselenggarakan di pelataran Masjid Banyumudal pada hari Jum'at Kliwon. Pada satu hari menjelang upacara dilaksanakan, kompleks makam Syeh Ibrohim Asmorokondi ramai dikunjungi oleh para peziarah. Kompleks makam ini terletak di sebelah tenggara masjid. Dalam kompleks makam ini terdapat makam istri Syeh Ibrohim Asmorokondi dan sanak keluarganya yang berada di luar bangunan cungkup.

\footnotetext{
Penyelenggara upacara ini adalah Takmir Masjid Banyumudal Desa
}

Kuwarisan. Pihak lain yang terlibat adalah perangkat desa dan seluruh anggota masyarakat desa, terutama muda-mudi yang bertugas membantu sejak tahap persiapan hingga pelaksanaan upacara tradisi ini. Pada malam puncak upacara banyak pedagang asongan yang ikut mengais rezeki, sehingga arena upacara menjadi seperti pasar malam. Mereka menjajakan makanan, pakaian, hasil kerajinan, dan lain sebagainya.

Sesuai dengan namanya, upacara khol ini merupakan bentuk penghormatan dan terima kasih kepada Kyai Syeh Ibrohim Asmorokondi sebagai tokoh Islam yang disegani karena keteladanan dan kearifannya dalam masyarakat. Peringatan pada bulan Muharram dalam ajaran Islam biasa dilakukan oleh penganut aliran Syiah yang memperingati kematian Hasan dan Husein secara besar-besaran. Dalam upacara tradisi khol di desa Kuwarisan ada sinkretisme budaya Jawa, yang tampak dari penentuan hari pelaksanaan yaitu bukan pada tanggal 10 Muharram tetapi pada malam Jum'at Kliwon. Dalam tradisi Jawa, malam Jum'at Kliwon sangat dikeramatkan dan diagungkan.

Upacara khol didahului dengan ritual ziarah ke makam Syeh Ibrohim Asmorokondi pada Rabu Pon malam Kamis Wage dan penjamasan pusaka peninggalan beliau di rumah juru kunci, kemudian dilanjutkan dengan lek-lekan di makam tersebut bagi orang yang ingin ngalap berkah. Sementara itu di masjid dikumandangkan puji-pujian semalam suntuk oleh para pemuda dan laki-laki dewasa, dan membaca Alqur'an. Pada pagi harinya kira- kira pukul 10-an ibu- ibu membawa ingkung ayam ke masjid dengan dilapisi daun pisang dan baki. Setelah sholat Jum'at, upacara khol dilaksanakan, dengan mengiring ingkung keliling jalan desa dekat masjid. Bapak-bapak yang telah menunaikan sholat Jum'at pulang ke rumah, sedangkan takmir masjid dan ibuibu mendengarkan ceramah pengajian dengan mengundang penceramah baik dari dalam maupun dari luar Kabupaten Kebumen. Tradisi membawa ingkung selain 
dilakukan oleh ibu-ibu juga oleh remaja puteri apabila jumlah ingkung yang dibawa lebih dari satu untuk setiap rumah. Setelah ingkung didoakan kemudian dibawa pulang ke rumah masing-masing untuk dimakan bersama anggota keluarga di rumah maupun dihantarkan kepada sanak keluarga yang berada di luar desa apabila jumlahnya banyak.

Tradisi membawa ingkung ayam jantan yang dibumbui dengan rempahrempah, kunyit, berambang, bawang, sereh, ketumbar, dan daun salam dengan kaki ayam yang terduduk dan utuh mempunyai arti bahwa orang Islam tunduk dan terduduk kepada Allah dengan pasrah diri. Ingkung ayam diletakkan di serambi masjid Banyumudal dan sisanya berada di halaman dan jalan-jalan sekitar masjid. Pada hari Jum'at segenap anggota keluarga datang ke masjid untuk melaksanakan upacara baik anak-anak, anak muda maupun orang dewasa (Hartatik, dkk., 2007: 112-121).

Sementara itu, upacara tradisi selikuran di Kabupaten Temanggung dilaksanakan di Puncak Gunung Sumbing. Upacara tradisi ini dilaksanakan pada tanggal 20 malam 21 setiap bulan Ramadan. Mereka datang ke puncak gunung untuk berdoa agar mendapat lailatul qodar dari Allah SWT karena di malam itu para malaikat turun ke bumi dari malam hingga pagi dan merupakan malam yang lebih baik dari 1000 bulan. Masyarakat di lereng Gunung Sumbing mencari tempat yang tinggi untuk berdoa dengan melakukan pendakian ke puncak gunung itu yang memiliki ketinggian 3.371 meter di atas permukaan laut.

Upacara tradisi itu berhubungan erat dengan seorang tokoh yang konon dimakamkan di Puncak Gunung Sumbing, yang dikenal dengan nama $\mathrm{Ki}$ Ageng Mangkukuhan. Tokoh ini sangat dihormati karena berjasa khususnya di bidang pertanian yaitu sebagai cikal bakal yang mengenalkan budi daya tanaman tembakau yang merupakan primadona dan mascot Kabupaten Temanggung. Ki Ageng Mangkukuhan banyak memberikan ajaran tentang cara bercocok tanam dengan memperhatikan tata musim atau pranoto mongso. Jika permulaan tahun Jawa jatuh pada hari Ahad, maka tahun itu disebut sebagai tahun dite koenobo, artinya tahun kelabang. Dalam tahun itu petani boleh menggarap sawah pada hari Rabu. Ajaran Ki Ageng Mangkukuhan yang lain adalah para petani apabila ingin menanam tanaman yang diambil daunnya, misalnya bayam, kubis, dan tembakau, maka hari baik untuk menanam adalah Senin atau Rabu. Akan tetapi, apabila berkeinginan menanam padi, jagung, gandum, dan sejenisnya, maka dipilih hari Kamis. Wujud penghormatan masyarakat terhadap Kia Ageng Mangkukuhan dilakukan dengan berziarah ke makamnya pada malam selikuran. Ziarah dilakukan oleh penduduk dengan berbondong-bondong membawa bunga untuk nyekar, selain mendapatkan lailatul qodar.

Dalam tradisi masyarakat Jawa, pemanjatan doa akan lebih khusuk dan bermakna apabila dilaksanakan di makam tokoh yang dikeramatkan karena mereka yang berdoa akan mendapat tuah darinya. Selain itu, jika dihubungkan dengan kepercayaan dalam agama Hindu/Budha, puncak gunung merupakan tempat yang baik untuk bertapa dan berdoa karena tempat yang tinggi merupakan tempat bersemayam dewa-dewa. Dengan keyakinan itu masyarakat berharap doanya di malam selikuran di puncak Gunung Sumbing untuk mendapat lailatul qodar dapat dikabulkan. Selain itu ada kepercayan yang berkembang dalam masyarakat Temanggung bahwa semakin sering berziarah ke makam Ki Ageng Mangkukuhan maka akan semakin tenang kehidupannya. Ada yang percaya bahwa jika ziarah telah dilakukan minimal 7 kali, maka kehidupan mereka akan mengalami kesempurnaan (Suara Merdeka, 30 Nopember 2002).

Perlengkapan upacara tradisi selikuran tidak banyak dan sifatnya tidak wajib. Hal ini barangkali berhubungan dengan kondisi medan yang cukup tinggi dan tidak mudah dijangkau. Perlengkapan yang biasa dibawa oleh para peziarah 
adalah bunga setaman yang digunakan untuk nyekar di makam Ki Ageng Mangkukuhan dan buku doa, misalnya buku yasin dan tahlil.

Upacara tradisi selikuran dilakukan dengan melakukan pendakian menuju ke puncak Gunung Sumbing pada hari ke-20 malam 21 bulan Ramadan. Pendakian ini juga menjadi petualangan yang menarik dan penuh dengan tantangan terutama saat mendaki bukit-bukit yang terjal. Peziarah dapat menikmati panorama alam yang elok terutama pada saat sang surya terbit di ufuk timur. Secara fisik, dataran di puncak gunung yang satu dengan lainnya memiliki karakteristik dan pesona yang berbedabeda. Dataran di puncak Gunung Sumbing, memiliki permukaan cekung menyerupai bathok (tempurung kelapa) yang terlentang, sehingga puncak permukaan gunung itu dikenal dengan "bathok mlumah".

Para pendaki dan peziarah yang mendaki dari Kacepit di Kecamatan Bulu akan masuk ke puncak Sumbing dari sisi timur. Di area itu terlihat hamparan padang pasir atau segara wedi yang luasnya hampir sama dengan lapangan sepak bola. Sedikit ke arah barat akan ditemukan kawah yang di sebelahnya terdapat gundukan batu yang diperkirakan sebagai makam Ki Ageng Mangkukuhan, di tempat inilah upacara dimulai.

Para peziarah mula-mula nyekar dengan menaburkan bunga yang dibawa ke atas makam sambil berdoa supaya arwah Ki Ageng Mangkukuhan diterima di sisi Tuhan Yang Mahakuasa. Setelah itu mereka memanjatkan doa-doa untuk mendapatkan lailatul qodar dari Allah SWT. Upacara di puncak Sumbing dipimpin oleh orang yang dituakan di tempat itu dan kemudian dilanjutkan dengan membaca doa-doa semalaman suntuk hingga terbitnya fajar. Mengingat arena yang digunakan merupakan medan yang berat dan berbahaya, pelaksanaan upacara tradisi ini juga melibatkan tim SAR dan jajaran kepolisian. Mereka bertugas menjaga keselamatan dan keamanan para peserta sejak pendakian maupun selama upacara (Iswari, dkk., 2007: 56-62).

\subsection{Upacara Buka Luwur di Makam Sunan Kudus di Kudus dan Khol Mbah Panggung di Tegal}

Upacara buka luwur di Kudus dilakukan dalam rangka penggantian luwur atau kain mori yang digunakan untuk membungkus jirat, nisan, dan cungkup makam Sunan Kudus. Upacara ini dilaksanakan di Tajug Masjid Menara Kudus di Desa Kauman Kecamatan Kota Kudus pada setiap tanggal 10 Asyuro (Muharram) yang konon bertepatan dengan wafatnya Sunan Kudus. Dengan demikian, tanggal 10 Asyuro telah ditetapkan sebagai waktu pelaksanaan ulang tahun wafatnya Sunan Kudus untuk setiap tahunnya. Buka luwur atau buka luhur adalah sebutan masyarakat untuk upacara ini, yang artinya membuka pusaka leluhur. Seusai buka luwur di makam Sunan Kudus, biasanya diikuti dengan buka luwur di makam-makam lain seperti makam Sunan Muria dan makam para ulama kharismatik di daerah Kudus.

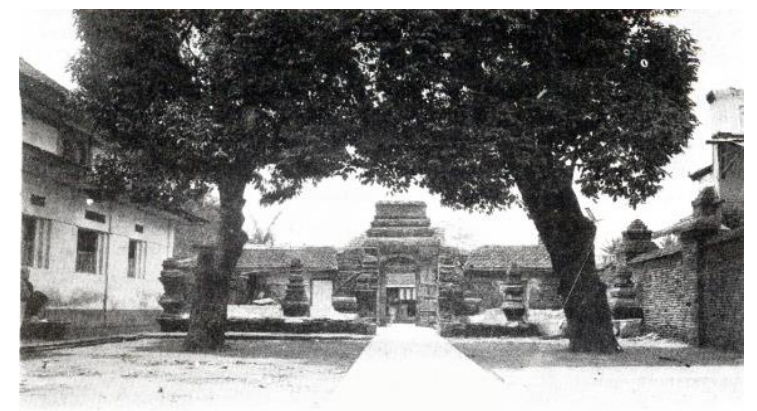

Gambar 1. Tajug, bangunan di sebelah kiri pintu gerbang masjid

Tujuan utama upacara ini adalah untuk memperingati kebesaran jasa Ja'far Shadiq, nama asli Sunan Kudus, dalam syiar Islam di Kudus yang pada waktu itu masih didominasi oleh pengikut agama Hindu, dan peran beliau dalam membesarkan kota Kudus. Oleh karena itu, sebelum acara inti penggantian luwur di makam Sunan Kudus berlangsung terlebih dahulu dilakukan penjamasan pusaka peninggalan Sunan Kudus, dilanjutkan dengan beberapa ritual yang berhubungan 
dengan syiar Islam seperti pembacaan Kitab Barzanji, tahlilan, khataman hapalan Alqur'an, pengajian, dan tak lupa pembagian nasi jangkrik yang tidak menggunakan lauk daging sapi sebagai salah satu warisan kearifan Sunan Kudus dalam menjaga toleransi dengan masyarakat yang masih beragama Hindu pada zamannya, tetapi menggunakan daging kerbau atau daging kambing.

Upacara ini juga dimaksudkan sebagai salah satu syiar Islam yaitu dalam rangka memperingati tahun baru Hijriyah. Itu sebabnya pengajian umum diselenggarakan pada malam hari sebelum penggantian luwur baru itu dilaksanakan. Pengajian disampaikan oleh ulama kharismatik yang ditunjuk oleh Pengurus Yayasan Masjid Menara dan Makam Sunan Kudus, bisa ulama dari daerah Kudus atau dari tempat lain. Puncak upacara ini adalah $\mathrm{khol}$ atau peringatan ulang tahun wafatnya Sunan Kudus. Dalam upacara ini selalu dilakukan pembacaan tahlil yang dipimpin oleh Imam Besar Masjid Menara yang diikuti oleh semua peserta upacara.

Masyarakat juga mempercayai bahwa upacara buka luwur sebagai selamatan dengan pembagian nasi jangkrik. Selain untuk mereka yang mengikuti upacara ini, nasi jangkrik juga diperuntukkan bagi para donatur, tamu undangan, dan panitia penyelenggara. Karena jumlahnya terbatas, nasi jangkrik sering diperebutkan yang menyebabkan beberapa orang sempat pingsan akibat berdesak-desakan untuk mendapatkan nasi itu. Upacara ini ditunggutunggu oleh masyarakat yang menginginkan berkah dari potongan luwur lama yang diyakini mempunyai banyak khasiat.

Penyelenggaraan upacara buka luwur dimulai sejak beberapa bulan sebelum acara puncak dilaksanakan, yaitu dengan membuat kepanitiaan yang terdiri dari imam besar Masjid Menara, para anggota Pengurus Yayasan Masjid Menara dan Makam Sunan Kudus, juru kunci Makam Sunan Kudus, beberapa ulama sepuh, dan para donatur yang memberikan dana bantuan untuk pelaksanaan upacara itu dan selamatan yang memerlukan beberapa ton beras, beberapa ekor kerbau dan kambing.

Juru kunci Makam Sunan Kudus dalam upacara itu bertugas menjamas pusaka peninggalan Sunan Kudus, khususnya keris dan tombak. Ritual ini berlangsung pada setiap bulan Dzulhijjah (Besar) atau pada bulan Muharram (Suro). Panitia yang terdiri dari Pengurus Yayasan Masjid Menara dan Makam Sunan Kudus bertugas melaksanakan beberapa kegiatan keagamaan seperti menyelenggarakan pementasan seni bernuansa Islam terbangan, pembacaan Kitab Barzanji, khataman Alqur'an, penyelenggarakan doa Rasul, santunan kepada anak yatim, dan yang tak kalah penting adalah memasak nasi serta daging kerbau dan kambing untuk membuat nasi jangkrik. Imam Besar Masjid Menara dalam hal ini bertugas membuka puncak upacara buka luwur dan memimpin doa untuk kelancaran seluruh rangkaian acara hingga selesai dilaksanakan di Makam Sunan Kudus.

Acara yang dilaksanakan pada setiap tanggal 10 Asyuro itu sebenarnya merupakan acara pemasangan luwur baru, sedangkan buka luwur-nya sendiri sejak 6 tahun terakhir dilakukan pada setiap tanggal 1 Asyuro. Puncak acara itu memberi kesan bahwa pada tanggal itulah hari wafatnya Sunan Kudus. Kesan ini timbul karena rangkaian acara pemasangan luwur selalu ditandai dengan acara tahlilan yang identik dengan acara khol pada umumnya. Tidak diketahui secara pasti tanggal wafatnya Sunan Kudus, namun ada yang memperkirakan bahwa tokoh ini wafat pada sekitar tahun $1555 \mathrm{M}$.

Sekitar seminggu sebelum
pelaksanaan upacara buka luwur, diselenggarakan penjamasan pusaka peninggalan Sunan Kudus berupa keris Ciptoko dan sepasang tombak berbentuk trisula yang biasa diletakkan di sebelah kiri dan sebelah kanan mihrab (pengimaman) Masjid Menara. Peninggalan yang lain berupa jubah putih, sajadah merah, sorban hijau, dan sapu tangan pembungkus ijazah 


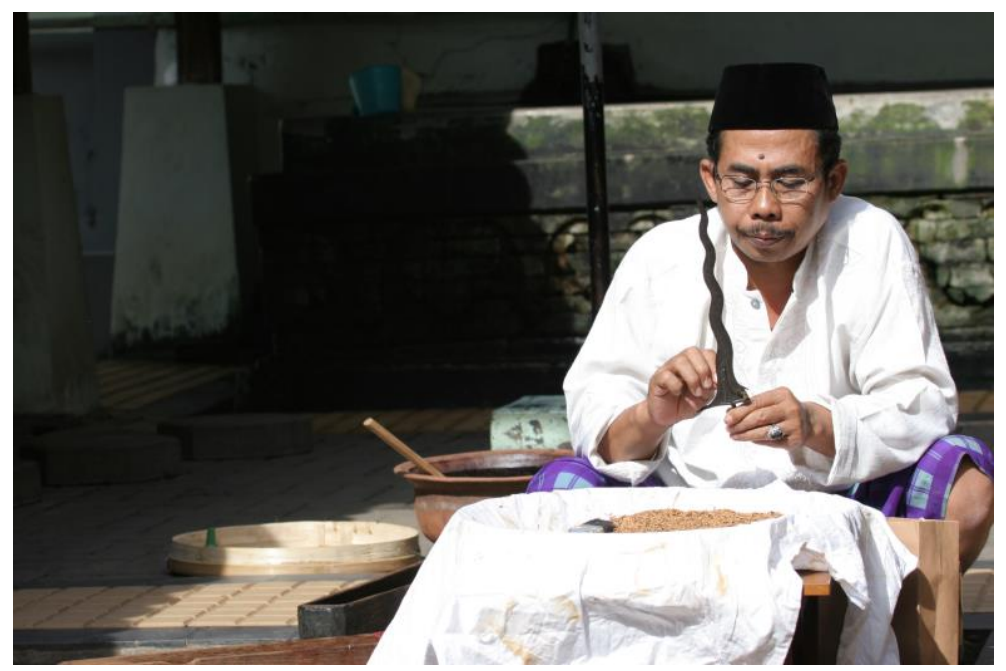

Gambar 2. Juru kunci menjamas pusaka peninggalan Sunan Kudus

wilayah (hadiah dari Amir Palestina), cukup dikeluarkan dari tempat penyimpanannya dan dijemur.

Upacara penjamasan itu selalu dihadiri oleh kerabat Sunan Kudus, para ulama, dan peziarah, yang setelah mengikuti upacara tradisi itu bersama-sama mengikuti selamatan atau tahlilan. Dalam kesempatan itu peziarah mendapat bagian nasi kenduri, dan disyaratkan untuk mencicipi jajan pasar agar memperoleh berkah. Penjamasan pusaka-pusaka ini selalu dilaksanakan pada bulan Besar (Dzulhijjah) atau Asyuro (Muharram) dengan tanggal yang tidak dapat ditentukan. Akan tetapi, untuk harinya sudah ditetapkan pada setiap Senin atau Kamis, sesudah hari Tasyriq, tanggal 11-13 Dzulhijjah. Konon, selama penjamasan ini keadaan cuaca selalu timbreng, yaitu kondisi cuaca tidak dalam keadaan terik dan tidak pula mendung apalagi hujan (Hartatik, dkk., 2008: 123-135).

Jasad Pangeran Panggung atau Mbah Panggung dimakamkan di Desa Panggung disertai dengan kedua anjing pengikutnya, Iman dan Tokid, yang dimakamkan di sebelah kanan dan kiri makam Mbah Panggung. Untuk mengenang jasa-jasa Mbah Panggung, masyarakat Tegal menggelar upacara khol setiap tahun sejak tahun 1954. Acara ini dimaksudkan untuk memohon berkah dari
Pangeran Panggung, yang bertujuan untuk menghormati, mendoakan, dan mengingat

Mbah Panggung sebagi pahlawan dunia-akhirat. Mbah Panggung hidup sebelum muncul kota Tegal, yang semula merupakan sebuah atol (pulau karang) yang dikelilingi laut. Tegal muncul dari bergabungnya atol itu dengan Pulau Jawa. Atol inilah yang digunakan oleh Mbah Panggung untuk bermunajad, di wilayah yang sekarang dikenal sebagai Kelurahan Panggung. Mbah Munib dari Mranggen mengatakan bahwa Mbah Panggung merupakan penasihat spiritual Raja Demak. Mbah Panggung merupakan keturunan Arab dengan nama Syayid Syarif Abdulrochman atau lebih dikenal dengan sebutan Abdulrochman. Dengan demikian Mbah Panggung diperkirakan hidup pada masa kerajaan Demak sekitar tahun 1478.

Pembiayaan dalam upacara khol Mbah Panggung berasal dari iuran sukarela dan sumbangan dari berbagai pihak. Upacara khol ini semula dilaksanakan pada tanggal 6 bulan Syaban dan dalam perkembangan dilakukan pada bulan Syahban pada malam minggu. Upacara khol ini dimulai pada Sabtu sore, yang diikuti dengan sunatan massal. 
Sehabis magrib, sebagian panitia dan juru kunci menuju (sowan) makam Mbah Panggung yang dilanjutkan dengan nglarung sesaji di laut Tegal. Sesaji ini berisi antara lain kepala kerbau dan jajan pasar serta berbagai macam makanan. Sebagian panitia yang lain mengikuti pawai yang dilaksanakan setelah sholat Isya dengan diiringi dengan seni terbangan. Pawai ini melalui jalan Pancasila-Kolonel Sudiarto dan kemudian masuk ke Jalan Arifin. Panitia khol dari tahun 2000-2008 berjumlah tetap yaitu 9 orang.

Tahlil yang dilakukan pada malam harinya mulai pukul 21.00-23.30 (malam khol dipimpin oleh ulama yang didatangkan dari luar daerah. Pada tahun 2008, misalnya, tahlil dipimpin oleh Habib Abdullah al Hadad dari Pekalongan. Pada keeseokan hari, daging kerbau dimasak dan dimakan bersama-sama pada acara tahlil akbar. Pagi harinya sekitar pukul 8.00 diadakan upacara khol dengan pembacaan yasin dan tahlil bersama-sama yang dipimpin Habib Yahya Al lyid dengan Habib Muhdor Al Jufri. Dalam perkembangan, setelah Habib Yahya Al lyid meninggal digantikan oleh Habib Muhdor Al Jufri dan Habib Muhsin Al Hamdan. Upacara khol Mbah Panggung juga diisi dengan sunatan massal, mujahadah, tablig akbar, dan berbagai macam doa untuk memohonkan maaf kepada Yang Maha Kuasa atas kesalahan Mbah Panggung dan para leluhur dan memohon keselamatan bagi anak-cucu dan seluruh warga masyarakat Panggung.

Upacara ini dihadiri oleh berbagai lapisan masyarakat dari berbagai golongan yang membaur menjadi satu. Dari acara ini tidak terlihat adanya perbedaan lapisan sosial masyarakat; yang terlihat hanyalah kerukunan dan keharmonisan di antara mereka. Selain itu, sejak awal kompleks makam Mbah Panggung sudah dijadikan makam umum bagi warga. Makam ini merupakan makam kuna, yang terlihat dari masih adanya makam keturunan Brawijaya dari Majapahit. Makam Mbah Panggung setiap hari dikunjungi warga yang ingin berziarah di tempat ini. Di daerah ini juga terdapat sumur yang pada masa lalu digunakan untuk mengambil sumpah seseorang dalam melakukan perbuatan dengan cara melemparkan sejumlah uang ke dalam sumur, yang dipercaya dapat membantu menyelesaikan permasalahan mengenai nilai-nilai moral yang dimiliki oleh masyarakat (Iswari, dkk., 2009: 73-85).

\section{Makna di Balik Upacara Tradisi}

Pelajaran yang dapat ditarik dari upacara-upacara tradisi khol di seputar makam tokoh-tokoh keramat di Jawa Tengah adalah sebagai berikut.

(1) Melestarikan budaya leluhur yang masih bertahan di tengah arus globalisasi yang semakin deras kehidupan dalam masyarakat.

(2) Menghargai para tokoh pendahulu yang dijadikan panutan dan tuntunan hidup dengan mendoakan di makam beliau lewat lantunan bacaan tahlil dan Alqur'an.

(3) Sifat kerukunan dan kegotongroyongan yang masih terlihat lewat kegiatan kerja bakti bersama, mempersiapkan makanan, iuran dana, dan lain sebagainya yang sekarang sudah mulai terkikis dalam masyarakat perkotaan.

(4) Bentuk rasa syukur kepada Allah SWT yang diujudkan dengan berdoa bersama dan melaksanakan makan secara bersama pada waktu upacara tradisi dilaksanakan.

(5) Menambah ilmu agama dengan cara mendatangkan mubalig untuk memberikan pengetahuan agama dan kehidupan baik untuk orang tua maupun generasi muda.

(6) Pelajaran bagi generasi muda supaya tetap menghormati dan mencintai budaya yang telah berkembang dan tetap mempertahankannya.

(7) Ajang silaturahmi di antara warga desa dan antara masyarakat desa dengan para pejabat dan masyarakat dari daerah lain yang datang dalam upacara tradisi itu. 


\section{Simpulan}

Upacara tradisi khol dalam masyarakat di sejumlah daerah di Jawa Tengah, khususnya yang pada masa Mataram Islam tercakup dalam wilayah Negara Agung, Mancanegara, dan Pasisiran, umumnya berhubungan dengan tokoh-tokoh yang mempunyai hubungan dengan agama Islam. Pihak-pihak yang terlibat dalam upacara tradisi ini adalah juru kunci makam, takmir masjid, tokoh masyaraakat, dan masyarakat umum baik yang tinggal di lingkungan makam tokohtokoh yang dikeramatkan maupun masyarakat dari luar desa dan daerah. Dana yang digunakan untuk membiayai pelaksanaan upacara-upacara tradisi itu sebagian besar berasal dari masyarakat.

Makna dan nilai- nilai yang dapat diambil dari pelaksanaan upacara tradisi di seputar tokoh keramat ini adalah jiwa solidaritas sosial yang masih lestari dalam masyarakat pendukung upacara tradisi itu. Hal itu tercermin dari kerukunan dan kegotongroyongan dalam penyelenggaraan upacara tradisi. Upacara tradisi khol juga merupakan perwujudan dari sikap masyarakat yang masih memegang teguh tradisi leluhur. Bagi generasi muda, upacara tradisi merupakan bentuk refleksi masa lalu dan dapat digunakan sebagai sarana pembelajaran kultural.

\section{DAFTAR PUSTAKA}

Hartatik, Endah Sri, dkk. 2007. Pengkajian dan Penulisan Upacara Tradisi di Kabupaten Kebumen. Semarang: Dinas Pendidikan dan Kebudayaan Propinsi Jawa Tengah.

2008. "Pengkajian dan Penulisan Upacara Tradisi di Kabupaten Kudus." Semarang: Dinas Pendidikan dan Kebudayaan Propinsi Jawa Tengah.

2009. "Pengkajian dan Penulisan Upacara Tradisi di Kabupaten Grobogan." Semarang: Dinas Kebudayaan dan Pariwisata Propinsi Jawa Tengah.

Iswari, Rini, dkk. 2007. "Pengkajian

dan Penulisan Upacara Tradisi di
Kabupaten Temanggung." Semarang: Dinas Pendidikan dan Kebudayaan Propinsi Jawa Tengah.

. 2008. "Pengkajian dan Penulisan Upacara Tradisi di Kabupaten Sukoharjo." Semarang: Dinas Pendidikan dan Kebudayaan Propinsi Jawa Tengah.

2009. "Pengkajian dan Penulisan Upacara Tradisi di Kota Tegal." Semarang: Dinas Kebudayaan dan Pariwisata Propinsi Jawa Tengah.

Gabriel, Ralph H. 1991. Nilai-nilai Amerika: Pelestarian dan Perubahan. Yogyakarta: Gadjah Mada University Press.

Koentjaraningrat.

1978/1979.

Pengantar Antropologi. Jakarta: Aksara Baru.

1987. Kebudayaan

Mentalitas dan Pembangunan. Jakarta: Gramedia.

Linton, Ralph. 1940. "Acculturation," dalam Ralph Linton, Editor. Acculturation in Seven American Indian Tribes. Gloucester: Peter Smith.

\section{Surat Kabar}

Suara Merdeka, 30 Nopember 2002. 